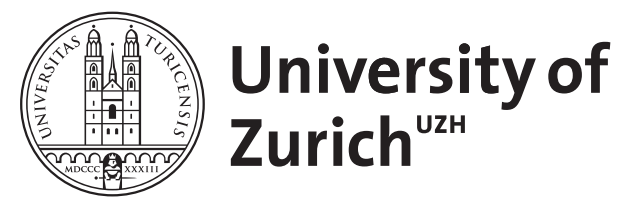

\title{
The electoral appeal of party strategies in postindustrial societies: when can
} the mainstream left succeed?

\author{
Abou-Chadi, Tarik ; Wagner, Markus
}

\begin{abstract}
Recent elections have revived the debate about the decline of social democracy, often attributed to the numerical decline in the working class and its alienation due to the mainstream left's economically centrist and socially liberal policy stances. To explain changes in these parties' fortunes, we instead argue that researchers need to analyze the preferences of key electoral groups on the main axes of political competition and the role of information-transmitting intermediaries in shaping these preferences. Specifically, we suggest that (1) mainstream left parties can win votes by taking up more investment-oriented positions if they (2) also take up liberal sociocultural positions and (3) do not face opposition from influential unions. We find support for these expectations using aggregate-level election results and individual-level survey responses. Our findings have important implications for our understanding of party success in advanced democracies and for empirical models of party competition more generally.
\end{abstract}

DOI: https://doi.org/10.1086/704436

Posted at the Zurich Open Repository and Archive, University of Zurich

ZORA URL: https://doi.org/10.5167/uzh-178898

Journal Article

Published Version

Originally published at:

Abou-Chadi, Tarik; Wagner, Markus (2019). The electoral appeal of party strategies in postindustrial societies: when can the mainstream left succeed? The Journal of Politics, 81(4):1405-1419.

DOI: https://doi.org/10.1086/704436 


\title{
The Electoral Appeal of Party Strategies in Postindustrial Societies: When Can the Mainstream Left Succeed?
}

\author{
Tarik Abou-Chadi, University of Zurich \\ Markus Wagner, University of Vienna
}

\begin{abstract}
Recent elections have revived the debate about the decline of social democracy, often attributed to the numerical decline in the working class and its alienation due to the mainstream left's economically centrist and socially liberal policy stances. To explain changes in these parties' fortunes, we instead argue that researchers need to analyze the preferences of key electoral groups on the main axes of political competition and the role of information-transmitting intermediaries in shaping these preferences. Specifically, we suggest that (1) mainstream left parties can win votes by taking up more investment-oriented positions if they (2) also take up liberal sociocultural positions and (3) do not face opposition from influential unions. We find support for these expectations using aggregate-level election results and individual-level survey responses. Our findings have important implications for our understanding of party success in advanced democracies and for empirical models of party competition more generally.
\end{abstract}

$\mathrm{n}$ recent years, many social democratic parties such as the Dutch PvdA or the French PS have suffered deep electoral decline. Coupled with the 2016 victory of Donald Trump in the United States and a simultaneous surge in support for populist radical-right parties in Europe, this has revived a decades-old debate about the crisis of the center left and social democracy. The public narrative strongly focuses on the parties' supposedly dwindling support among its traditional base, the working class. This is often linked to what is seen as the mainstream left's centrist policy shift and its unwillingness to take tough stances on immigration. However, this view is at odds with scholarly work that has pointed to the increasing relevance of educated middle-class voters for the success of mainstream left parties in postindustrial societies (Gingrich and Häusermann 2015; Kitschelt 1994). Hence, we currently lack a clear understanding of how party strategies and social structure interact in determining the electoral fate of mainstream left parties.

We provide an analytical framework and a thorough empirical analysis of the fortunes of the mainstream left. To successfully analyze the electoral fortunes of social democratic parties, we argue that three steps are necessary: (1) determine the main political dimensions of party competition; (2) identify relevant electoral groups and their preferences within those dimensions; and (3) identify important intermediaries that transmit information on party positions to core voters. Using this approach, we develop theoretical expectations and analyze empirically the success of moderate left parties in Europe and English-speaking democracies.

Our theoretical assumptions for the three steps are as follows. First, the new main axes of political competition can no longer be described using left and right alone but include the distributive dimension of investment versus consumption as well as an additional cultural, liberal-authoritarian dimension (Häusermann 2010a; Kitschelt 1994). Following Beramendi et al. (2015), investment and consumption policies are a shorthand for two broader economic visions: an orientation of government toward increasing individuals' market participation and productivity (investment) versus efforts to protect them from market forces and make up for losses of income (consumption). The investment-consumption dimension has arguably become a crucial dimension in political competition due to the fundamental changes in political preferences resulting from socioeconomic transformations based on

Tarik Abou-Chadi (tarik.abou-chadi@uzh.ch) is an assistant professor in the Department of Political Science, University of Zurich, Affolternstrasse 56, 8050 Zurich. Markus Wagner (markus.wagner@univie.ac.at) is a professor in the Department of Government, University of Vienna, Rathausstraße 19/1/9, 1010 Vienna, Austria.

Data and supporting materials necessary to reproduce the numerical results in the article are available in the JOP Dataverse (https://dataverse.harvard.edu /dataverse/jop). An online appendix with supplementary material is available at https://dx.doi.org/10.1086/704436.

The Journal of Politics, volume 81, number 4. Published online July 16, 2019. http://dx.doi.org/10.1086/704436

(C) 2019 by the Southern Political Science Association. All rights reserved. 0022-3816/2019/8104-0017\$10.00 
technological innovation, a shift to a service economy, and increasing global integration of capital and labor (Beramendi et al. 2015; Kriesi et al. 2008).

Second, these demand-side transformations affect the preferences of electoral groups in distinct ways. Our approach to studying electoral groups builds on Oesch's (2006b) social class distinctions based on work logics and task structures that helps to explain voters' distributive preferences (see also Kitschelt and Rehm 2014). The recent socioeconomic transformations of class structures are particularly relevant for mainstream left parties, as their electoral success was built on economic demands and partisan ties among working-class voters, whose share of the electorate is declining (Best 2011). Mainstream left parties have a general incentive to increase their policy-based appeal among the growing groups of sociocultural professionals and high-skilled labor market outsiders, which are both predominantly female. We argue that these efforts will be most successful when they can attract these groups through investment-oriented economic positions as well as liberal cultural positions.

Third, such policy shifts can have negative effects among existing supporters, especially if the shifts are amplified by intermediaries. Mainstream left parties that move toward investment-oriented positions may alienate their core social base of working-class voters (Karreth, Polk, and Allen 2013), especially when strong and centrally organized unions as core information intermediaries manage to mobilize voters against these shifts. Alienated working-class voters may then shift their support to more radically left parties or mainstream and radical-right parties that more strongly appeal to them on the liberal-authoritarian dimension.

Our empirical analysis uses data from the Manifesto Project (Volkens et al. 2017) and applies a novel measure of parties' positions on investment versus consumption policies. First, we show at the aggregate level that mainstream left parties increase their vote share by shifting toward more investmentoriented policies, but only when they also take liberal positions on second-dimension issues and where unions are limited in their capacity to mobilize against those shifts. Second, we test our microlevel mechanisms using data from the European Social Survey (ESS). Among sociocultural and other professionals (such as business administrators or technical experts), support for mainstream left parties is higher if they pursue investment-oriented policies, particularly if coupled with cosmopolitan positions. Among manual workers, investmentoriented policy positions only decrease support for mainstream left parties among union members.

While our findings have important direct implications for understanding the changing electoral fortunes of mainstream left parties, we also contribute to the more general debate on the electoral effectiveness of party policy shifts. Comparative research on the effects of party positioning has focused on the left-right dimension. These studies often only find small or no effects at all (Adams 2012). These findingsor rather the lack thereof - constitute a dilemma for research on party competition, since spatial models predict that party positions matter for parties' fortunes at the polls. In contrast, our argument centers on the impact of a transformed political space and takes the social, economic, and ideological changes in postindustrial societies seriously as a source of political preferences. Finally, our analysis highlights the general role of political intermediaries in shaping the risks and opportunities created by party responses to changing social environments.

\section{ELECTORAL PREFERENCES AND THE TRANSFORMATIONS OF POSTINDUSTRIAL SOCIETIES} Since the postwar period, technological change and the shift from industrial to service-oriented economics have led to a decrease of the size of the working class; an increase in highly educated, sociocultural professionals as a share of the work force; as well as an increased duality of the labor market (Beramendi et al. 2015; Kitschelt 1994; Rueda 2005). Occupational structures have changed, and different social groups experience distinct levels of protection from the forces of global markets and domestic economic transformations.

Studies of the socioeconomic composition of postindustrial societies therefore need to move beyond hierarchical distinctions of working class and bourgeoisie or lower, middle, and upper class and acknowledge horizontal differences in occupational structures (Oesch 2006a, 2006b). While the "democratic class struggle" between the working class and bourgeoisie was the core of electoral competition in industrialized democracies until at least the 1970s (Bornschier 2010; Lipset 1960), the demand side of political competition has since changed fundamentally because of the politicization of several issues that cut across the traditional class divide. First, aspects of socioeconomic status such as skill specificity (Iversen and Soskice 2001) and employment type (Burgoon and Dekker 2010) now strongly shape individuals' policy preferences. Hence, social investment (Hemerijck 2013), new social risks (Bonoli 2005), and "modernizing compromises" (Häusermann 2010a) have become core themes of social policy. Second, issues such as gender equality, immigration, and European integration have formed a new dimension of political competition (Kitschelt 1994; Kriesi et al. 2008). Thus, the preferences of key electoral groups in a multidimensional space are now characterized by the rising importance of investment-consumption issues and the cultural dimension. 
In addition to reshaping preferences, socioeconomic transformations affect how mainstream left parties can build crossclass alliances. This challenge is not new: mainstream left parties have always had to garner electoral support beyond their working-class base in order to be electorally viable (Przeworski and Sprague 1986). Because this might lead mainstream left parties to alienate their core constituency and be less able to mobilize voters on the basis of their working-class identity, Przeworski and Sprague (1986) famously predicted that the numerical decline of the working class would lead to the decline of social democratic parties. In contrast, we build on Kitschelt (1994) to argue that social democratic parties can forge new cross-class alliances that allow them to stay electorally relevant. This argument also differs from Boix (1998), who expects social democratic investment policy strategies because of their ideological predisposition rather than their vote-seeking strategies.

While the transformations of postindustrial societies have led to an erosion of the traditional support base of the mainstream left (Best 2011), they have also provided them with new opportunities for other electoral alliances. Mainstream left parties can now appeal to new or growing segments of the electorate such as well-educated, female voters and highskilled workers in internationally competitive industries (Gingrich and Häusermann 2015; Häusermann, Picot, and Geering 2013; Kitschelt 1994). However, appealing to these groups entails the risk of alienating working-class supporters (Karreth et al. 2013). Whether they can successfully balance this risk with increased appeal among new electoral groups will depend on their own strategies as well as contextual factors affecting the cost and benefits of their strategic behavior.

\section{APPEALING TO PROFESSIONALS WITH INVESTMENT-ORIENTED POLICIES}

We expect that, under certain conditions, mainstream left parties can increase their electoral support by moving toward investment-oriented policy positions. While questions of left and right, understood as the distinction between preferences for state intervention in the economy versus the free allocation of resources through markets, have not completely lost their relevance, the range of policy proposals within this dimension has fundamentally shrunk in postindustrial societies (Evans and Tilley 2012; Kitschelt 2012). In their place, decisions over investment versus consumption policies are now crucial to understanding distributive politics (Beramendi et al. 2015). Parties of the mainstream left can focus on investment versus consumption quite independently of their general position toward state versus market. While a shift toward investment is often regarded as going hand in hand with a shift toward more market-oriented positions (Keman 2011), the reality of party positioning is more nuanced than that (Pierson 2001; Taylor-Gooby 2004).

Social policies in advanced capitalist societies have increasingly focused on social investment (Bonoli 2013; Hemerijck 2013; Morel, Palier, and Palme 2012). Such policies constitute activating and (re)commodifying measures to improve, change, or preserve human capital and skills. These policies are generally regarded as efficient responses to the challenges of mature welfare states and are often popular with the general public. However, the pressures of limited resources and increasing public debt mean that social investment policies (such as child care funding or higher spending on education) imply strategic trade-offs. They either lead to higher debt or, when cost neutral, involve higher taxes or reduced spending on other policies (Busemeyer and Garritzmann 2017). Political strategies over social investment and education are a core component of political competition in postindustrial societies (Busemeyer 2009; Busemeyer, Franzmann, and Garritzmann 2013). At the voter level, citizens also favor either social investment or passive transfers and consumption policies (Fossati and Häusermann 2014; Garritzmann, Busemeyer, and Neimanns 2018).

Like Beramendi et al. (2015), we build on this literature but treat the distinction of investment and consumption as a shorthand for a more general opposition between two types of growth strategies. Investment is thus not limited to specific social policies but extends to state efforts to increase productivity and economic integration. Consumption includes not only social expenditures such as pensions and unemployment benefits but also measures to protect workers from market forces (Beramendi et al. 2015, 15). Investment and consumption are the two poles of a dimension of distributive politics on which parties choose their positions. Several scholars demonstrate how partisan dynamics affect the politics of investment, most notably education, and relate it to the attempts of social democratic parties to appeal to middle-class voters (Ansell 2010; Busemeyer 2009; Busemeyer et al. 2013; Kraft 2017). However, none of these studies empirically test the electoral consequences of these decisions for political parties.

For mainstream left parties, it is important that highly educated voters with generalized skills (e.g., sociocultural professionals) strongly favor policy packages that focus on investment over consumption policies (Fossati and Häusermann 2014; Garritzmann et al. 2018; Gingrich 2017; Marx 2014). Hence, while these groups show moderate to low support for redistribution (Garritzmann et al. 2018; Kitschelt and Rehm 2014), they support activation and investment policies. To appeal to these voters, mainstream left parties have an incentive to shift toward greater investment. Such policy shifts include an increase in investment in education, child care, or active labor 
market policies. Hence, in the changing sociodemographic composition and political space of postindustrial societies we should expect that more investment-oriented positions should be electorally beneficial for mainstream left parties. We therefore expect:

H1. More investment-oriented policy positions increase the vote share of mainstream left parties.

\section{WORKING-CLASS REACTIONS: THE ROLE OF UNIONS AS INTERMEDIARIES}

However, shifting policy positions toward investment may alienate the mainstream left's core electorate, manual workers, as they can be seen as recommodifying citizens (Gingrich and Ansell 2015; Karreth et al. 2013). Low-skilled workers with specific skills are especially likely to oppose investmentoriented recommodification (Häusermann 2010a; Häusermann, Kurer, and Schwander 2015). Moreover, the workingclass constituency of mainstream left parties consists to a large degree of labor market insiders (i.e., full-time employed wage earners with permanent contracts; Lindvall and Rueda 2014; Rueda 2005). Insiders generally have less interest in investment-oriented policies and instead prefer passive labor market policies and job protection (Rueda 2005). In contrast, high-skilled and female labor market outsiders strongly favor social investment policies (Häusermann et al. 2015). Focusing policies on social investment and labor market activation will potentially alienate labor market insiders (Häusermann et al. 2015; Lindvall and Rueda 2014). Therefore, adapting to the preferences of new segments of the electorate necessarily entails the risk of de-alignment of core workingclass constituencies.

However, this dilemma will not be equally strong or relevant in all contexts but will depend on whether investmentoriented policies are made meaningful for these voters (Gingrich 2014). Unions are crucial actors in this because they can raise the salience of such policy shifts and mobilize core voters against them. Unions are key intermediaries for political information (Iversen and Soskice 2015; Kim and Margalit 2017; Lohmann 1998; Mosimann and Pontusson 2017), traditionally closely linked to mainstream left parties (Arndt and Rennwald 2016), and generally known as defenders of traditional welfare schemes and consumption-oriented policies (Häusermann $2010 \mathrm{~b})$. They largely represent the interests of labor market insiders and, as they are male dominated, tend to be less responsive to new social risks. While unions do not generally oppose measures of social investment such as the expansion of education, they place less emphasis on addressing new social risks and argue for the protection of workers and classic consumption schemes such as public pensions (Häusermann 2010a, 2010b). Unions can shape voters' behavior as they provide information and cues on government policies and parties' issue positions and thus affect how they are perceived, especially by working-class constituencies (Iversen and Soskice 2015; Mosimann and Pontusson 2017). Unions actively shape their members' preferences, so differences in attitudes between their members and others cannot be reduced to selection effects (Kim and Margalit 2017). However, unions' potential to frame investment-oriented policies is greater when they are centrally organized and can more directly affect their members' opinions. Strong unions provide a crucial source of information and a deliberative social network that affects political attitudes (Iversen and Soskice 2015).

Hence, we argue that de-alignment from parties of the mainstream left crucially depends on the mobilizing and informational capacity of unions. Where unions are well organized and strong and have better opportunities for coordinated policy making, it is much more likely that labor market insiders will be disenchanted by investment-oriented policies and that these preferences in turn affect their vote choice. Investmentoriented policies should then be less beneficial to mainstream left parties as they are more likely to alienate their core constituency. We therefore expect:

H2. When unions are strong and centrally organized, investment-oriented policy positions will have less positive effects on mainstream left parties' vote share than when unions are weaker.

\section{THE CONDITIONING IMPACT OF THE CULTURAL DIMENSION}

Political competition has been fundamentally transformed as mainly new radical-right and left-libertarian parties have politicized a second dimension of political preferences (AbouChadi 2016; Wagner and Meyer 2017). In general, questions surrounding the basic principles of the organization of society have become the dominant dimension of political preferences for many (Kitschelt 1994; Kitschelt and Rehm 2014). The two main components of this shift are (1) an increase of the importance of the integration/demarcation conflict and (2) a mobilization of issues surrounding post-material-value change (Häusermann and Kriesi 2015). These conflicts can be tied to social groups. First, the divide between demarcation and integration is linked to the winners and losers of processes such as globalization and integration and related issues such as immigration and cultural identity (Kriesi et al. 2008). Educated professionals belong to the winners of globalization, and those in sociocultural occupations view internationalism and immigration very positively (Kitschelt and Rehm 2014). Second, post-material-value change and the social movements of the 
1960s have led to a politicization of issues such as gender equality, self-expression, and secularization (Flanagan and Lee 2003; Inglehart 1977). Educated female voters in particular have an interest in policies that promote gender equality and self-expression. When mainstream left parties want to appeal to a new, more educated, and female voter segment, shifting toward investment policies is not enough. To do so, they also need policy positions in line with the preferences of these voters on second-dimension issues (i.e., liberal stances on the second dimension). We therefore expect:

H3. Investment-oriented policy positions will affect mainstream left parties' vote shares more positively when they are coupled with liberal second-dimension positions.

Our hypotheses are based on assumptions about the policy preferences among different social groups such as labor market insiders or sociocultural professionals. While many of these preferences are well documented (Häusermann et al. 2015; Kitschelt and Rehm 2014; Rueda 2005), the debate about these is still ongoing (Emmenegger 2009). While investment policies are generally popular (especially in the case of education spending), when people face trade-offs between investment orientation and higher taxes or reduction in other welfare provisions other cleavages emerge (Busemeyer and Garritzmann 2017; Busemeyer and Neimanns 2017). Hence, we formulate and empirically test individual-level corollaries that follow from our hypotheses.

The crucial question is how social class affects voting behavior at the individual level. Following hypothesis 1, we should expect that professionals are more likely to vote for mainstream left parties when these take more investmentoriented positions. For hypothesis 2, it is crucial to demonstrate how unions affect working-class voters' reactions to investment positions. While we cannot directly test union mobilization, union membership should at least moderate the effect of investment positions: investment-oriented positions should negatively affect working-class union members' propensity to vote for the mainstream left. Finally, hypothesis 3 implies that among professionals, investment-oriented policy positions will affect the probability of voting for a mainstream left party more positively when coupled with liberal seconddimension positions.

\section{MEASURING MAINSTREAM LEFT PARTY POSITIONS ON INVESTMENT CONSUMPTION}

For each country's mainstream left (i.e., Social Democratic or Labour) party, we measure positions on the investmentconsumption scale using data from the Manifesto Project
(Volkens et al. 2017; app. 1 presents the full list of parties and countries; apps. 1-16 are available online). In addition to covering a broad range of countries for an extended time period, the project's coding scheme allows us to capture party views on investment versus consumption. Specifically, we treat the following codes as relating to the investment end of the policy dimension: incentives: positive; protectionism: negative; technology and infrastructure; and education expansion. We treat the following codes as indicating consumption-oriented policy positions: protectionism: positive; Keynesian demand management; controlled economy; and labour groups: positive. We calculate positions on this dimension using the log scale approach (Lowe et al. 2011), so we transform the percentages into sentence counts and take the natural logarithm of the ratio of statements (adding 0.5 to each side to avoid zeros):

$$
\text { investment position }=\ln \left(\frac{\text { investment }+0.5}{\text { consumption }+0.5}\right)
$$

Such a measure derived from manifesto data necessarily cannot perfectly capture parties' investment/consumption positions. Hence, appendix 2 provides a detailed outline of our decisions on which items to include. Two face-validity checks show that investment-consumption policy positions vary across party families in expected ways (fig. A2.1; figs. A2.1-A15.2 are available online) and that mainstream left parties have moved toward investment-oriented policy stances over time (fig. A2.2). Appendixes 3 and 4 document three robustness checks for our coding decisions: our findings hold for a measure that only includes the items most closely related to our concept and for measures that leave out one issue at a time. Figures A3.5 and A3.6 demonstrate that we reach substantively similar conclusions if we treat investment/consumption as two separate emphasis variables rather than as one dimension. Positions on the investment/consumption dimension also do more than capture broader left-right positions, as our results do not hold in models that use the Manifesto Project's left-right ("rile") scores (app. 9).

We control for party positions on the state-market dimension, in order to ensure that our findings are not due to positions on this dimension (see app. 5 for coding details). Building on Wagner and Meyer (2017), we calculate seconddimension positions based on issues that capture migration, law and order, traditional morality, internationalism, and the European Union. Figure A5.1 shows that social democratic parties are more libertarian/cosmopolitan than conservative and nationalist parties. Figure A5.2 shows that there is no clear correlation between investment/consumption and second-dimension positions. 


\section{AGGREGATE-LEVEL ANALYSIS}

We begin by modeling mainstream left parties' vote shares at the aggregate level. Parties' vote shares are included in the manifesto data set (Volkens et al. 2017). Our sample consists of 22 advanced industrial countries since 1975 . We use this sample since our theory's range applies to advanced industrial societies where previously strong mainstream left parties face incentives to reorient their policy program.

Hypothesis 2 states that investment-oriented policies have a less positive impact on mainstream left parties' vote shares where unions are strong and centralized. We use data from the ICTWSS (Visser 2013) to build an additive index that combines union density and their wage coordination centralization. This allows us to approximate how centrally organized unions are and how many workers they can potentially reach. Since not all unions are aligned with left-wing parties, we add a third variable to our composite measure. It includes the share of union members not represented by Christian or professional and mostly academic peak associations (Arndt and Rennwald 2016). The resulting indicator has a theoretical range of $0-3$ and an empirical range of 1.21 2.77. We find similar effects using either union density or wage coordination centralization alone, with union density showing the strongest moderating effect (app. 7). There is no correlation between union strength and investment-consumption positions (fig. A7.1).

We control for the level of unemployment and gross domestic product (GDP) growth in the year of the election since they may affect voter responses to investment-consumption positions; these measures are taken from Brady, Huber, and Stephens (2014). As our argument rests on the transformation toward a postindustrial society, we include a control variable for de-industrialization, measured as the share of workers in nonmanufacturing and nonagricultural sectors (Brady and Lee 2014). Since the effects of the policy positions of mainstream left parties may be conditional on the competitive context (Bale et al. 2010; Watson 2015), we control for the presence of a radical-right or radical-left party; we code presence as 1 if a radical-right/radical-left party achieved $1 \%$ of the vote or more in the previous election (Döring and Manow 2018). Robustness checks in which we control for the vote share of these parties produce results consistent with those below (app. 8). In additional analyses, we control for the presence of Green parties (app. 8). We also control for whether the party was in government at the election and for the position of the mainstream right party on the investment-consumption dimension; we take the most investment-oriented position if there are several mainstream right parties.

We model the vote share of mainstream left parties using ordinary least squares regression models. To account for serial autocorrelation, we include a lagged dependent variable. We cluster standard errors by party. We also include party fixed effects to account for country- and party-level differences in the average success of mainstream left parties. Party fixed effects control for country- and party-specific and time-constant unobserved heterogeneity related to factors such as the party organization, welfare state regime, or electoral system. We thus focus on over-time variation within countries (looking at one party per country) and exclude cross-sectional variation. We consider how the strategic behavior of mainstream left parties within the specific systems of the sample countries affects their electoral fortunes against the country average and not compared to mainstream left parties in other countries. Note that the inclusion of a lagged dependent variable and unit fixed effects can potentially bias our estimation (Nickell 1981); all our findings hold if we exclude the fixed effects. Our findings are not driven by one specific country: findings remain robust to using a jackknife-like procedure and rerunning our analyses excluding one country at a time (app. 6).

Table 1 presents the key mainstream left vote share basic models and those including the full set of controls. Models 1 and 2 show that investment-oriented policies are generally associated with a larger vote share for mainstream left parties, but this association is not statistically significant at the conventional .05 level. A 1 unit increase on the investmentconsumption scale is predicted to increase the mainstream left party's vote share by about $1 \%$. Since the standard deviation of the investment-consumption scale is 1.12 for our sample, a 1 unit change is akin to a 1 SD change. Hence, investmentoriented policies may generally increase support to a smallish extent, but we cannot support hypothesis 1 . These results are broadly consistent with Keman's (2011) findings concerning the electoral effect of Third Way policy stances. Turning to other variables included in the model, positions on seconddimension issues have no discernible effect. The presence of a radical-right party has a statistically significant and substantial negative effect on mainstream left vote share. Mainstream left parties lose votes when they are part of the government before the election $(p=.064)$.

Table 1 models 3 and 4 show that the effect of positions on the investment-consumption scale depends on union influence (hypothesis 2). Figure 1 shows that, for high values of union strength (i.e., when social democratic unions are centrally organized and influential), mainstream left parties do not gain votes if they take an investment-oriented position.

In contrast, when union influence is weaker, investmentoriented policies positively affect vote share. Specifically, a 1 unit shift toward investment-oriented positions is predicted to lead to around a $3 \%$ increase in vote share. Hence, investment-oriented policy positions increase the vote share 
Table 1. Regression Results, Aggregate-Level Analyses

\begin{tabular}{|c|c|c|c|c|c|c|}
\hline & Model 1 & Model 2 & Model 3 & Model 4 & Model 5 & Model 6 \\
\hline Lagged vote share & $\begin{array}{l}.456^{* * *} \\
(.0938)\end{array}$ & $\begin{array}{l}.432^{* * *} \\
(.0980)\end{array}$ & $\begin{array}{l}.449^{* * *} \\
(.0873)\end{array}$ & $\begin{array}{l}.419^{* * *} \\
(.0815)\end{array}$ & $\begin{array}{l}.442^{\star * *} \\
(.0878)\end{array}$ & $\begin{array}{l}.425^{\star * \star} \\
(.0957)\end{array}$ \\
\hline Investment & $\begin{array}{c}.764 \\
(.648)\end{array}$ & $\begin{array}{c}.972 \\
(.701)\end{array}$ & $\begin{array}{r}5.307^{\star} \\
(2.518)\end{array}$ & $\begin{array}{l}7.043^{\star *} \\
(2.423)\end{array}$ & $\begin{array}{l}.570 \\
(.551)\end{array}$ & $\begin{array}{l}.813 \\
(.637)\end{array}$ \\
\hline Union influence & $\begin{array}{c}2.106 \\
(1.488)\end{array}$ & $\begin{array}{c}.213 \\
(1.395)\end{array}$ & $\begin{array}{c}4.601^{*} \\
(1.988)\end{array}$ & $\begin{array}{c}2.964 \\
(1.814)\end{array}$ & $\begin{array}{c}2.140 \\
(1.349)\end{array}$ & $\begin{array}{c}.589 \\
(1.118)\end{array}$ \\
\hline Union influence $x$ investment & & & $\begin{array}{r}-2.266^{*} \\
(1.125)\end{array}$ & $\begin{array}{c}-2.974^{* *} \\
(1.009)\end{array}$ & & \\
\hline Second-dimension position & $\begin{array}{c}-.421 \\
(.509)\end{array}$ & $\begin{array}{l}.0759 \\
(.426)\end{array}$ & $\begin{array}{c}-.559 \\
(.516)\end{array}$ & $\begin{array}{r}-.0655 \\
(.394)\end{array}$ & $\begin{array}{l}.477 \\
(.502)\end{array}$ & $\begin{array}{c}.725^{\star} \\
(.318)\end{array}$ \\
\hline Investment $\times$ second-dimension position & & & & & $\begin{array}{c}-1.183^{* * *} \\
(.320)\end{array}$ & $\begin{array}{c}-.971^{\star *} \\
(.331)\end{array}$ \\
\hline Party in government $(0 / 1)$ & $\begin{array}{r}-2.825^{\star} \\
(1.158)\end{array}$ & $\begin{array}{c}-2.418 \\
(1.353)\end{array}$ & $\begin{array}{c}-2.813^{\star *} \\
(1.068)\end{array}$ & $\begin{array}{c}-2.432 \\
(1.247)\end{array}$ & $\begin{array}{c}-3.332^{\star *} \\
(1.169)\end{array}$ & $\begin{array}{c}-2.951^{\star} \\
(1.374)\end{array}$ \\
\hline Mainstream right position on investment & & $\begin{array}{c}.372 \\
(.504)\end{array}$ & & $\begin{array}{c}.400 \\
(.491)\end{array}$ & & $\begin{array}{c}.263 \\
(.493)\end{array}$ \\
\hline State-market position & & $\begin{array}{r}-.0799 \\
(.419)\end{array}$ & & $\begin{array}{c}-.00517 \\
(.394)\end{array}$ & & $\begin{array}{l}.0419 \\
(.404)\end{array}$ \\
\hline Radical-right party $(0 / 1)$ & & $\begin{array}{c}-3.857^{\star \star} \\
(1.434)\end{array}$ & & $\begin{array}{c}-3.755^{\star *} \\
(1.376)\end{array}$ & & $\begin{array}{r}-.0291 \\
(.242)\end{array}$ \\
\hline Radical-left party $(0 / 1)$ & & $\begin{array}{c}3.834^{\star *} \\
(1.459)\end{array}$ & & $\begin{array}{l}4.526^{* \star} \\
(1.432)\end{array}$ & & $\begin{array}{r}-.0227 \\
(.175)\end{array}$ \\
\hline Unemployment & & $\begin{array}{r}-.0427 \\
(.261)\end{array}$ & & $\begin{array}{l}.00230 \\
(.236)\end{array}$ & & $\begin{array}{c}-.0291 \\
(.242)\end{array}$ \\
\hline GDP growth & & $\begin{array}{c}-.0183 \\
(.173)\end{array}$ & & $\begin{array}{r}-.0275 \\
(.157)\end{array}$ & & $\begin{array}{c}-.0227 \\
(.175)\end{array}$ \\
\hline Deindustrialization & & $\begin{array}{l}-9.307 \\
(13.03)\end{array}$ & & $\begin{array}{r}-15.30 \\
(12.83)\end{array}$ & & $\begin{array}{l}-8.524 \\
(12.35)\end{array}$ \\
\hline Party fixed effects & Yes & Yes & Yes & Yes & Yes & Yes \\
\hline Constant & $\begin{array}{l}16.62^{\star * *} \\
(4.319)\end{array}$ & $\begin{array}{l}25.71^{\star *} \\
(9.087)\end{array}$ & $\begin{array}{l}11.99^{\star} \\
(5.336)\end{array}$ & $\begin{array}{l}23.96^{* *} \\
(9.179)\end{array}$ & $\begin{array}{l}16.81^{\star * *} \\
(3.893)\end{array}$ & $\begin{array}{l}24.13^{\star *} \\
(8.890)\end{array}$ \\
\hline$R^{2}$ & .82 & .92 & .83 & .92 & .83 & .92 \\
\hline
\end{tabular}

Note. Standard errors in parentheses. $N=173$.

${ }^{*} p<.05$.

${ }^{* *} p<.01$.

${ }^{* * *} p<.001$.

of mainstream left parties only in countries where weak, decentralized unions do not have the capacity to successfully mobilize against them. This interaction effect also explains why the overall effects in models 1 and 2 are negligible.

Table 1 models 5 and 6 show how the effect of positions on the investment-consumption dimension depends on the second-dimension policy positions of a party. As figure 2 shows, investment-oriented positions are less electorally successful if the party takes an authoritarian/nationalist position: the effect of a 1 unit change in investment orientation is about $2.8 \%$ at -1.7 on the second-dimension policy scale and about
$0.1 \%$ at +0.7 (this is $1 \mathrm{SD}$ below and above the mean seconddimension policy position). So, for more authoritarian/nationalist positions on the cultural dimension, investmentoriented policies have no statistically significant effect. Hence, for mainstream left parties, investment-oriented policies are more likely to increase electoral support if coupled with a libertarian-cosmopolitan policy stance.

\section{INDIVIDUAL-LEVEL ANALYSIS}

We now turn to additional microlevel analyses in order to confirm the individual-level mechanisms that are hypothesized 


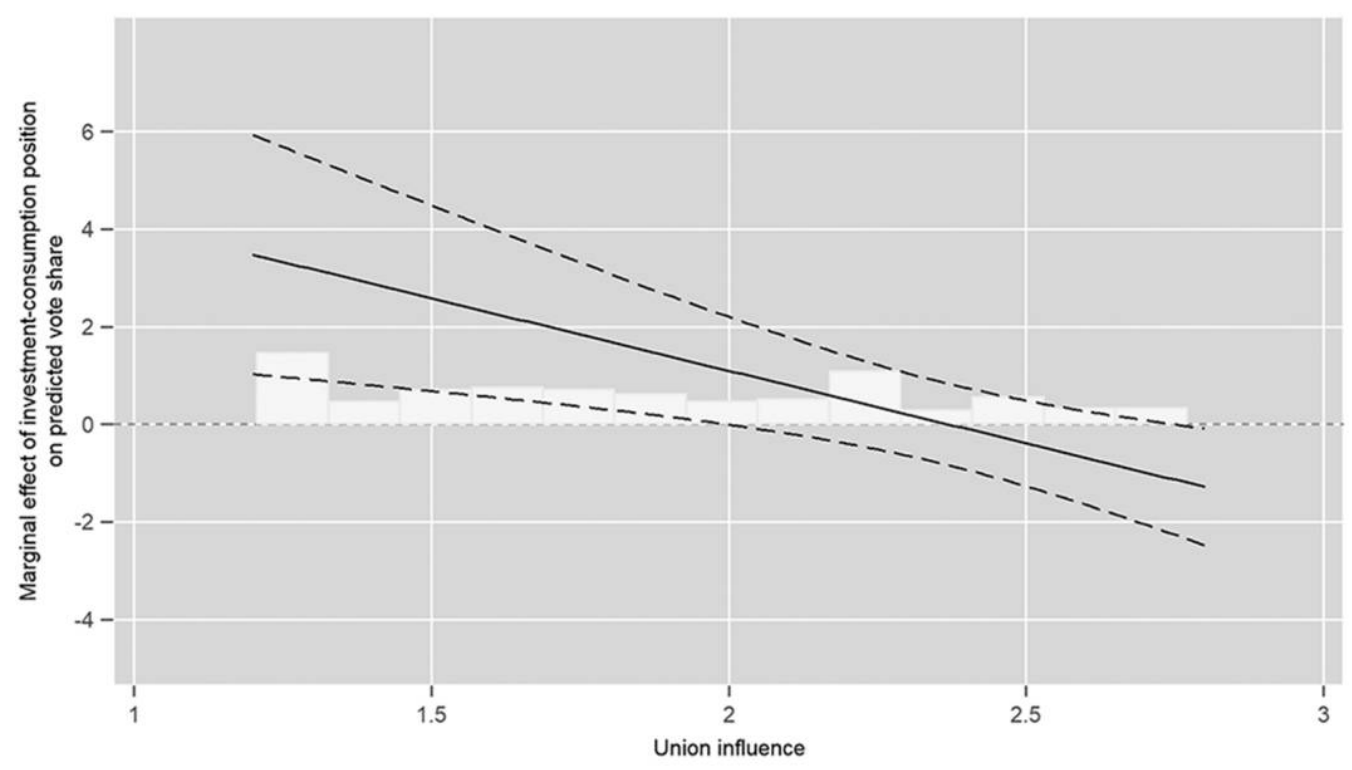

Figure 1. Marginal effect on the vote share of a mainstream left party of investment policy position conditional on union influence. Based on table 1 model 4; $95 \%$ confidence interval shown. Histogram of union influence shown below marginal effects plot. All figures were produced using Bischof's (2017) graphics scheme for Stata.

to underlie these trends. Our aggregate-level analysis built on hypothesized reactions among different voter subgroups, in particular working-class and professional voters. In this study, we match data on individual-level voting decisions with party positioning on the investment-consumption dimension to check whether these reactions plausibly underlie the patterns we find at the aggregate level. We use data from 56 surveys conducted in 17 countries as part of the ESS (see app. 10). Our outcome variable is voting for the major mainstream left party or parties in each country (see app. 1). Since the ESS is not a postelection study, we use a recall question; voters largely remember their vote choice accurately (van Elsas et al. 2014). Those who voted for a mainstream left party are coded as 1 , all other voters as 0 . We restrict our analysis to self-declared

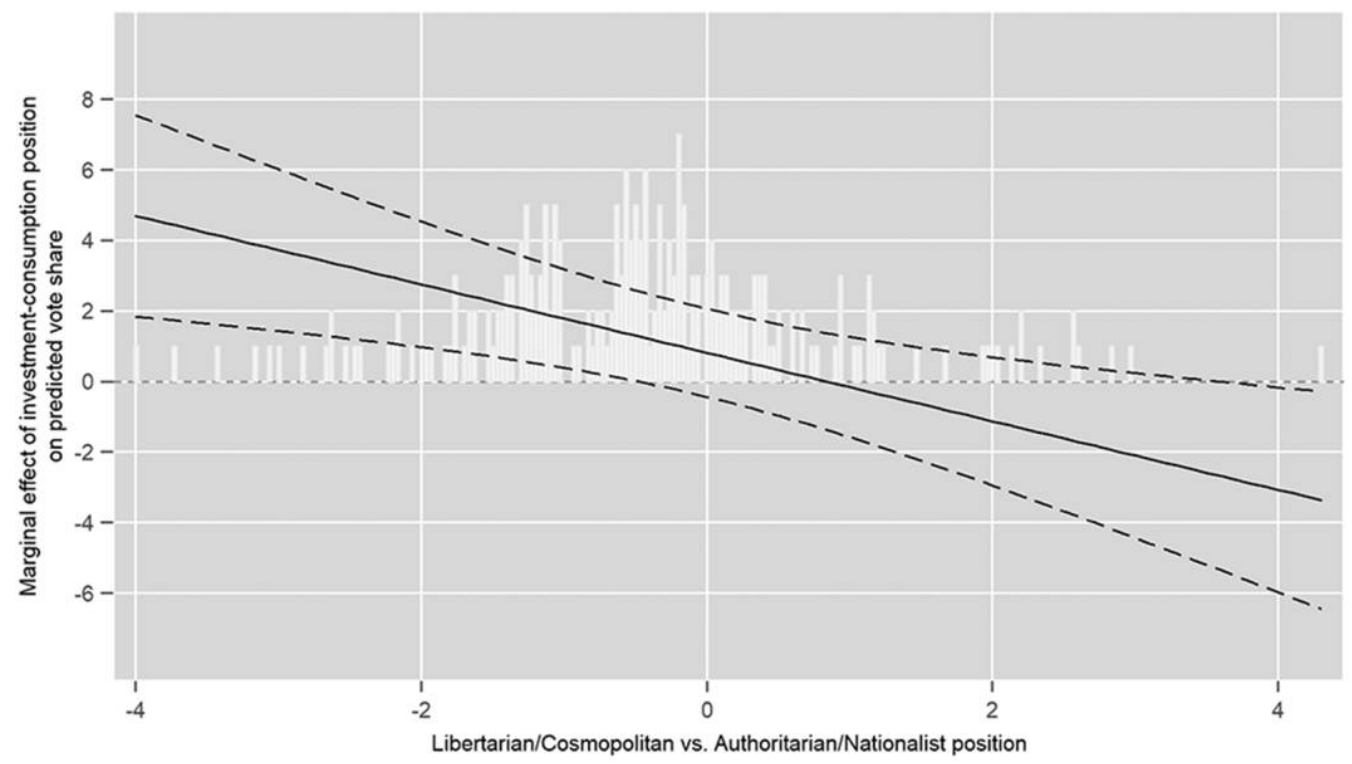

Figure 2. Marginal effect on the vote share of a mainstream left party of investment policy position conditional on second-dimension policy positions. Based on table 1 model 6; 95\% confidence interval shown. Histogram of second-dimension policy positions shown below marginal effects plot. 
voters; our findings remain identical if nonvoters are coded as 0 rather than as missing (app. 12).

Following Oesch (2006a), we divide respondents into two class groups: professionals (sociocultural, managerial, and organizational professionals) and manual workers (skilled craftspeople and all unskilled routine employees; see app. 10 for coding details). We expect these groups to react differently to mainstream left party strategies. To test this, each survey is matched with an election manifesto coded by the Manifesto Project, with ideological scales measured as in the aggregate-level study. We then examine whether working-class members react negatively to investment-oriented positions, particularly if they are union members; we distinguish between current and former members as well as those who have never been a union member. We also test whether professionals react positively to investment-oriented positions, particularly if these are combined with liberal second-dimension positions.

We control for identification with the mainstream left party since partisans are less likely to punish parties for shifting positions (Karreth et al. 2013); results do not differ substantively if we do not include this variable (app. 13). We also control for the left-right position, religious attendance, education level, age, gender, and political interest of respondents. We do not control for income because of missing values (but see app. 15). At the level of parties, we control for whether the party was the incumbent, the investment-consumption position of the most pro-investment mainstream right competitor, the vote share of the party at the last election (Döring and Manow 2018), and GDP growth in the year of the election, from the Organization for Economic Cooperation and Development database. Following Schmidt-Catran and Fairbrother (2016), we run multilevel models with random effects for each survey and each country. We use the ESS design weights as probability weights.

Table 2 presents the key models for mainstream left parties for manual workers (models 1 and 2) and professionals (models 3 and 4). Model 1 shows that, among manual workers, voting for mainstream left parties is significantly associated with being female and having a lower interest in politics and a lower level of education. Union membership has a positive effect on voting for a mainstream left party, but investmentoriented policy positions do not. However, model 2 shows that the effect of investment-consumption positions is conditional on whether manual workers are union members. Figure 3 presents the predicted effect of investment-consumption positions on the probability of voting for the moderate left for nonunion members and union members. The effect of investment-oriented policy positions is not distinguishable from zero for nonunion manual workers. In contrast, for union members the effect of investment-oriented policy po- sitions is negative. The size of the effect is substantial, with a $10 \%$ reduction in the predicted probability of voting for very investment-oriented mainstream left parties compared to very consumption-oriented mainstream left parties. This corresponds to receiving $10 \%$ less support among this electoral group. The effect of moving from 0.33 to 2.03 on the investment scale (i.e., a 2 SD change around the mean, holding all other variables at their observed values) is a $5.5 \%$ reduction in the probability of voting for the mainstream left party.

Union membership conditions how manual workers react to mainstream left investment-consumption positions. This is consistent with our argument that labor market insiders, who are more likely to be in unions, have less interest in investment-oriented policy positions. Further analysis shows that the interaction effect between union membership and investment-consumption party positions is stronger when union influence is greater (app. 14). Our analysis does not constitute a direct test of whether union mobilization against such policies drives our aggregate-level findings. Our results show that union membership only positively affects mainstream left vote share if these parties do not move too far toward investment-oriented policies. For professionals, there is no equivalent interaction between investment-oriented positions and union membership (app. 11).

Next, we test whether second-dimension positions affect mainstream left support among sociocultural and other professionals (table 2 models 3 and 4). Model 3 shows that voting for mainstream left parties among professionals is statistically significantly associated with identifying with that party, leftright views, education, and a lower interest in politics. The more a mainstream left party positions itself toward investment rather than consumption, the more likely professionals are to vote for that party. However, when, as in model 4 , we interact our indicator for a parties' libertarian/cosmopolitan position with their investment-consumption position, it becomes clear that this positive impact depends on the seconddimension position of the mainstream left party.

Figure 4 shows that mainstream left parties gain from an investment-oriented policy stance among sociocultural professionals only if these parties have a cosmopolitan position. Mainstream left parties that are positioned more toward authoritarian/nationalist positions do not gain from investmentoriented policies. This effect is substantively important: if the party is relatively cosmopolitan, a standard deviation change in investment policy position around the mean leads to a $4.2 \%$ increase in the probability that professionals will vote for the mainstream left party. In other words, $4.2 \%$ more professionals are predicted to support the party with this combination of positions. (This is the effect of moving from 0.33 to 2.03 on the investment scale; i.e., a 2 SD change around the mean, holding 
Table 2. Regression Results, Individual-Level Analyses (European Social Survey)

\begin{tabular}{|c|c|c|c|c|}
\hline & \multicolumn{2}{|c|}{ Manual Workers } & \multicolumn{2}{|c|}{ Professionals } \\
\hline & Model 1 & Model 2 & Model 3 & Model 4 \\
\hline \multirow[t]{2}{*}{ Investment } & -.0873 & .0357 & $.153^{*}$ & $.155^{\star}$ \\
\hline & $(.0994)$ & $(.113)$ & $(.0775)$ & $(.0628)$ \\
\hline \multirow[t]{2}{*}{ Current union member } & $.405^{\star \star}$ & $.799^{* * *}$ & .159 & .158 \\
\hline & $(.138)$ & $(.222)$ & $(.0952)$ & $(.0951)$ \\
\hline \multirow[t]{2}{*}{ Former union member } & .123 & .475 & .0640 & .0647 \\
\hline & $(.126)$ & $(.292)$ & $(.119)$ & $(.119)$ \\
\hline \multirow[t]{2}{*}{ Investment $\times$ current union member } & & $-.279^{* *}$ & & \\
\hline & & $(.100)$ & & \\
\hline \multirow[t]{2}{*}{ Investment $\times$ former union member } & & -.228 & & \\
\hline & & $(.140)$ & & \\
\hline \multirow[t]{2}{*}{ Second-dimension position } & .0353 & .0267 & .00822 & .0496 \\
\hline & $(.0627)$ & $(.0682)$ & $(.0529)$ & $(.0511)$ \\
\hline \multirow[t]{2}{*}{ Investment $\times$ second-dimension position } & & & & $-.0804^{\star}$ \\
\hline & & & & $(.0326)$ \\
\hline \multirow[t]{2}{*}{ State-market position } & -.0308 & -.0338 & .0122 & .0194 \\
\hline & $(.0399)$ & $(.0391)$ & $(.0287)$ & $(.0256)$ \\
\hline \multirow[t]{2}{*}{ Investment, mainstream right } & .125 & .127 & .0562 & .0200 \\
\hline & $(.0733)$ & $(.0780)$ & $(.0635)$ & $(.0609)$ \\
\hline \multirow[t]{2}{*}{ Rural residence ( $1-5$ scale, $1=$ big city, $5=$ countryside) } & -.0822 & -.0804 & -.0208 & -.0206 \\
\hline & $(.0671)$ & $(.0666)$ & $(.0364)$ & $(.0364)$ \\
\hline \multirow[t]{2}{*}{ Highest level of education (1-5 scale) } & $-.126^{\star * *}$ & $-.125^{\star * *}$ & $-.111^{\star *}$ & $-.111^{\star *}$ \\
\hline & $(.0381)$ & $(.0372)$ & $(.0386)$ & $(.0387)$ \\
\hline \multirow[t]{2}{*}{ Age of respondent (in years) } & .0102 & .00935 & .00244 & .00255 \\
\hline & $(.0147)$ & $(.0146)$ & $(.0185)$ & $(.0186)$ \\
\hline \multirow[t]{2}{*}{$\operatorname{Age}^{2}$} & -.0000927 & -.0000856 & -.0000686 & -.0000698 \\
\hline & $(.000126)$ & $(.000125)$ & $(.000162)$ & $(.000163)$ \\
\hline \multirow[t]{2}{*}{ Left-right position ( $0-10$ scale $)$} & -.172 & -.172 & $-.271^{\star * *}$ & $-.270^{\star \star \star}$ \\
\hline & $(.0928)$ & $(.0926)$ & $(.0460)$ & $(.0458)$ \\
\hline \multirow[t]{2}{*}{ Female $(0=$ no, $1=$ yes $)$} & $.163^{* * *}$ & $.160^{\star * *}$ & -.0694 & -.0684 \\
\hline & $(.0477)$ & $(.0485)$ & $(.0570)$ & $(.0571)$ \\
\hline \multirow[t]{2}{*}{ Religious attendance (1-7 scale) } & -.0585 & -.0582 & -.0302 & -.0303 \\
\hline & $(.0346)$ & $(.0348)$ & $(.0352)$ & $(.0352)$ \\
\hline \multirow[t]{2}{*}{ Political interest ( $1-4$ scale, $4=$ high) } & $-.285^{\star * *}$ & $-.278^{* * *}$ & $-.178^{\star * *}$ & $-.177^{\star * *}$ \\
\hline & $(.0564)$ & $(.0564)$ & $(.0402)$ & $(.0401)$ \\
\hline \multirow[t]{2}{*}{ Party identification $(0=$ no, $1=$ yes $)$} & $4.156^{* * *}$ & $4.150^{\star * *}$ & $3.770^{\star * *}$ & $3.771^{\star * *}$ \\
\hline & $(.219)$ & $(.219)$ & $(.182)$ & $(.182)$ \\
\hline \multirow[t]{2}{*}{ GDP growth } & $-.0630^{*}$ & $-.0596^{\star}$ & $-.113^{* * *}$ & $-.121^{* * *}$ \\
\hline & $(.0306)$ & $(.0296)$ & $(.0337)$ & $(.0331)$ \\
\hline \multirow[t]{2}{*}{ Incumbent $(0=$ no, $1=$ yes $)$} & -.150 & -.158 & -.178 & -.189 \\
\hline & $(.163)$ & $(.156)$ & $(.140)$ & $(.134)$ \\
\hline \multirow[t]{2}{*}{ Vote share at previous election } & $.0261^{\star *}$ & $.0260^{\star *}$ & .00915 & .00951 \\
\hline & $(.00966)$ & $(.00948)$ & $(.00678)$ & $(.00599)$ \\
\hline Constant & -.723 & -.934 & .318 & .361 \\
\hline & $(.755)$ & $(.769)$ & $(.545)$ & $(.531)$ \\
\hline Variance (country) & .0319 & .0361 & .0822 & .0812 \\
\hline & $(.0527)$ & $(.0524)$ & $(.0674)$ & $(.0637)$ \\
\hline
\end{tabular}




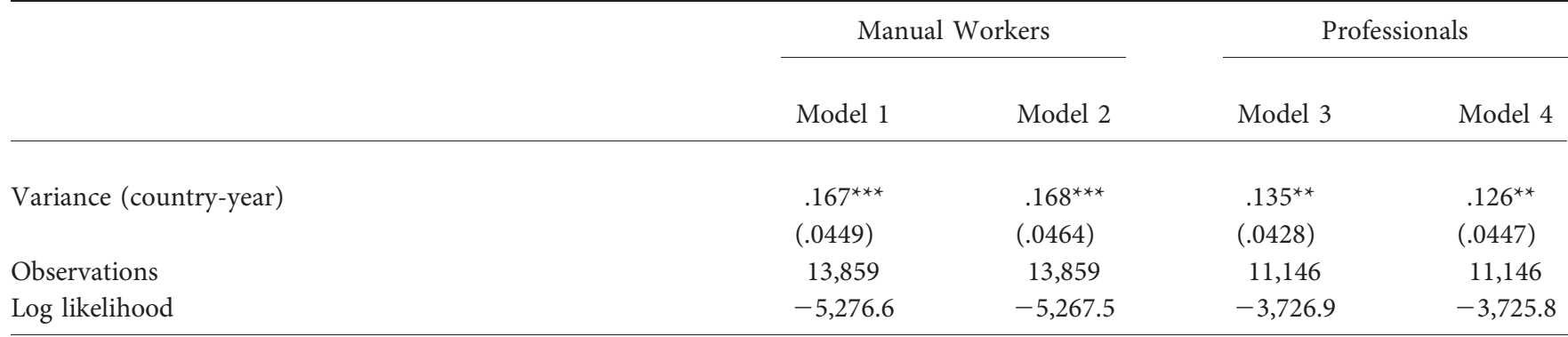

Note. Standard errors in parentheses. For coding of social groups, see app. 10.

${ }^{*} p<.05$.

$* * p<.01$.

${ }^{* * *} p<.001$.

second-dimension positions at a standard deviation below its observed mean and all other variables at their observed values.) Note that the removal of two outliers with high values on the second dimension (see fig. 4) does not change the results; in addition, the interaction effect between the two dimensions is not present among manual workers (app. 11).

\section{CONCLUSION}

Contemporary mainstream left parties can find relative electoral success if they can use newly relevant economic topics to appeal to professionals while also maintaining support among their traditional working-class base. Our results show that mainstream left parties can successfully appeal to professional voters, but to do so they need to bundle investment- oriented economic stances with culturally liberal positions. At the same time, moving toward investment-oriented policies can create electoral losses by reducing support among the working class, especially if unions mobilize against policy shifts. Hence, moving toward investment-oriented policies makes sense for mainstream left parties only if gains among professionals outweigh losses among the working class, and this will partly be determined by the strength of unions and the overall ideological package presented by mainstream left parties.

All of this should not imply that there is a simple winning strategy or equilibrium solution for the success of mainstream left parties. How a party strategy in a single election affects its vote share of course depends on a multitude of factors, most notably the behavior of other parties. Our aim

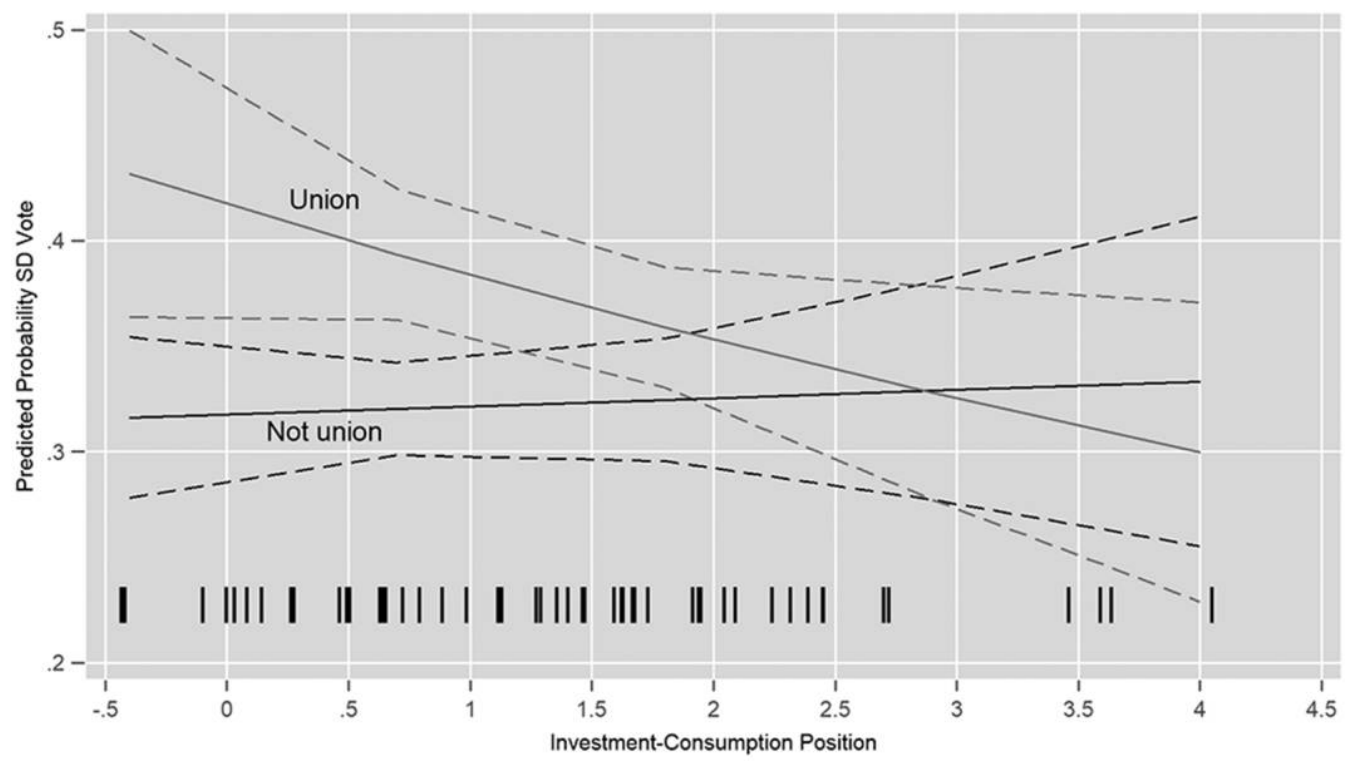

Figure 3. Manual workers: predicted probability of voting for a mainstream left party conditional on union membership and investment-consumption policy position. Based on table 2 model 2; 95\% confidence intervals shown. Other variables held at their observed values. "Pipes” at bottom indicate observed values for investment-consumption positions. 


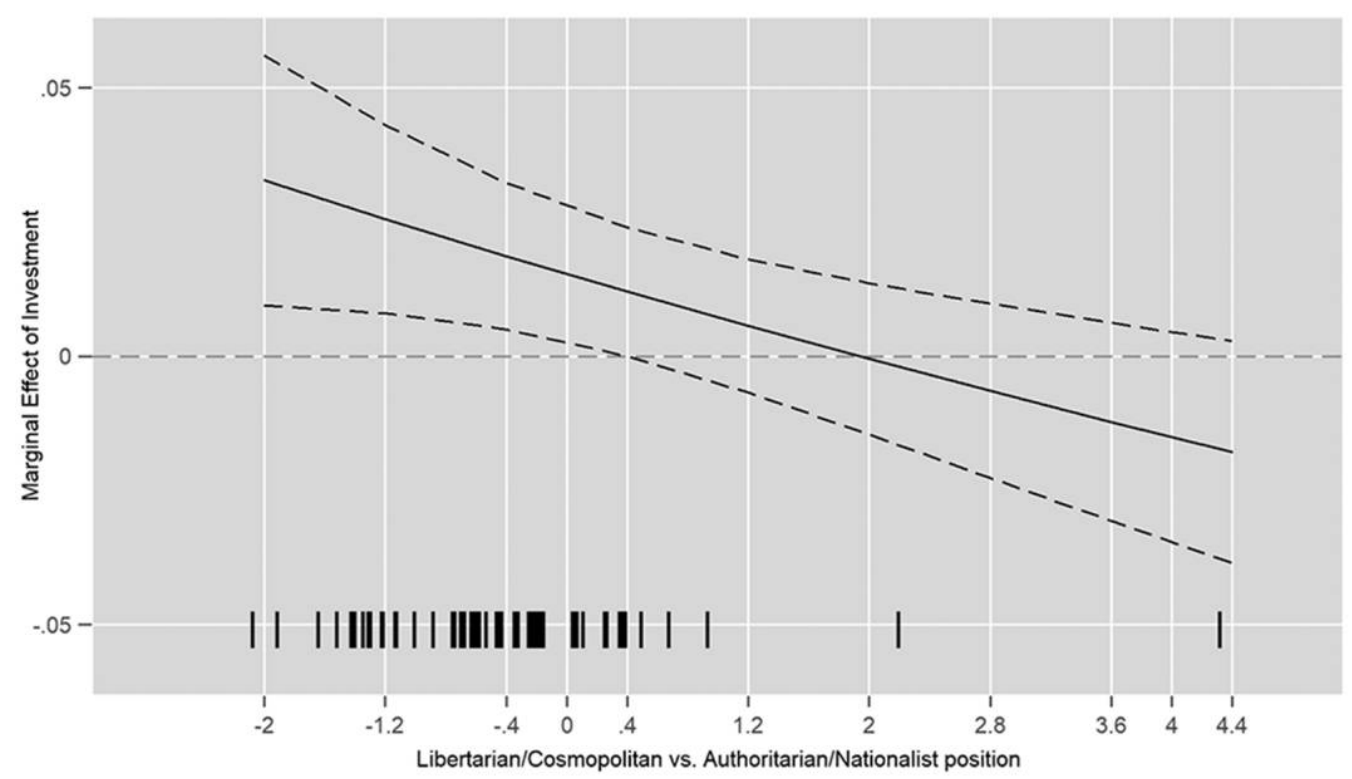

Figure 4. Professionals: marginal effect on the probability of voting for a mainstream left party of investment policy position conditional on cosmopolitan policy positions. Based on table 2 model 4; 95\% confidence intervals shown. All other variables held at their observed values. "Pipes" at bottom indicate observed values for investment-consumption positions.

here was to formulate broader expectations for mainstream left parties on the basis of the declining relevance of the working-class vote and the potential for crucial support among new middle-class groups. Nevertheless, our results hold implications for applications of spatial models to real-world elections. We have shown that spatial models tailored to contemporary political contexts in terms of issues and societal groups can better help us understand the electoral fortunes of political parties. Moving beyond our case, researchers who want to explain how party policy shifts are related to electoral results first need to answer several important questions. Which electoral groups can the party appeal to, and do these groups have important political intermediaries? And, what are the preferences of these groups on the key dimensions that determine party preferences and vote choice? Answers to these questions will allow researchers to design measures and models that more accurately capture the patterns and tradeoffs in party competition.

Four future lines of inquiry could be pursued based on our results. First, how do the competitors of mainstream left parties react to these parties' policy shifts on the investmentconsumption and liberal-authoritarian dimensions? Party competition is inherently dynamic, raising the question of how other parties react to and capitalize on changes in mainstream left party strategy. Moreover, while recent research on class voting has focused on the lack of party distinctiveness on a general left-right dimension (Evans and Tilley 2012), our research implies that we should focus instead on the effects of convergence and divergence on investment-versus- consumption and on second-dimension issues. Future research should also consider the extent to which factors such as issue salience, competence, and ownership factor into the ability of mainstream left parties to retain and attract voters.

Second, future work should examine in particular the role of immigration as a newly dominant issue in the politics of advanced industrial economies (van der Brug et al. 2015). Kitschelt and Rehm (2014) highlight the important distinction between moral "grid" issues on the one hand and identitybased "group" issues on the other. Immigration poses a challenge particularly to mainstream left parties: while many voters in their working-class base may favor a tougher stance, professionals may recognize the benefits of open borders. While there exists a broad literature on the working-class support of the radical right (e.g., Rydgren 2012), there is surprisingly little evidence on how political competition surrounding immigration affects the electoral fortunes of social democratic parties. How social democratic parties address this challenge and how their response plays out electorally will be an important question for future research.

Third, we argued that intermediaries play an important role in determining how electoral groups react to party policy positions and shifts. We took the well-established case of unions, which can choose to either communicate and justify policy choices to their associated electorate or mobilize against choices. We emphasize the role of union centralization and coverage and mainly focus on the role of unions as information intermediaries. Further research should be able to trace more closely the mechanisms by which unions mobilize against 
shifts toward investment and away from consumption. Moreover, other types of intermediaries may also play important roles: for example, the antiglobalization movements in the early 2000s or popular protests after the financial and Euro crisis may have also played a role in determining reactions to the mainstream left. Hence, future work should study the potential role of other intermediaries, in particular looser social movements.

Finally, while this article was concerned with the ideology of the mainstream left, there is potentially an analogous development to be explored on the mainstream right. These parties - Christian Democrats, Liberals, and Conservativesmay be able to position themselves toward consumptionoriented policies to gain votes among manual workers. However, for these parties there are three dangers: the radical right as a competitor for the same voter segment, second-dimension issues such as immigration as newly salient vote choice motivators, and resistance from those groups from which they gathered their traditional support. Hence, it may be that the mainstream right faces similar opportunities and costs as mainstream left parties, and this should be explored in future research.

Overall, our work has underlined that the current political, social, and economic context presents perhaps unprecedented complexities to mainstream parties. Building permanent, stable coalitions of voters is unlikely to become easier in the coming decades, likely leading to a continuing erosion of formerly dominant parties.

\section{ACKNOWLEDGMENTS}

Previous versions of this manuscript were presented at the annual meeting of the European Political Science Association in Brussels 2016, the Elections, Public Opinion and Parties conference at the University of Kent 2016, the workshop Party Competition and Challenges of Post-industrial Societies at Humboldt University Berlin 2016, the Political Behaviour Seminar at CEVIPOF/Sciences Po Paris, and the colloquium of the Mannheim Centre for European Social Research 2017. For valuable feedback, we would like to thank Jane Gingrich, Silja Häusermann, Ellen Immergut, Mark Kayser, Herbert Kitschelt, Heike Klüver, Thomas Meyer, Sergi Pardos-Prado, David Rueda, and Jae-Jae Spoon. We would especially like to thank Christoph Arndt and Line Rennwald for generously sharing their data on union membership with us. We also thank the anonymous reviewers and the editor for their excellent suggestions.

\section{REFERENCES}

Abou-Chadi, Tarik. 2016. "Niche Party Success and Mainstream Party Policy Shifts: How Green and Radical Right Parties Differ in Their Impact." British Journal of Political Science 46 (2): 417-36.
Adams, James. 2012. “Causes and Electoral Consequences of Party Policy Shifts in Multiparty Elections: Theoretical Results and Empirical Evidence." Annual Review of Political Science 15 (1): 401-19.

Ansell, Ben W. 2010. From the Ballot to the Blackboard: The Redistributive Political Economy of Education. Cambridge: Cambridge University Press.

Arndt, Christoph, and Line Rennwald. 2016. "Union Members at the Polls in Diverse Trade Union Landscapes.” European Journal of Political Research 55 (4): 702-22.

Bale, Tim, Christoffer Green-Pedersen, André Krouwel, Kurt R. Luther, and Nick Sitter. 2010. "If You Can't Beat Them, Join Them? Explaining Social Democratic Responses to the Challenge from the Populist Radical Right in Western Europe.” Political Studies 58 (3): 41026.

Beramendi, Pablo, Silja Häusermann, Herbert Kitschelt, and Hans-Peter Kriesi. 2015. "Introduction: The Politics of Advanced Capitalism.” In Pablo Beramendi, Silja Häusermann, Herbert Kitschelt, and HansPeter Kriesi, eds., The Politics of Advanced Capitalism. New York: Cambridge University Press, 1-64.

Best, Robin E. 2011. “The Declining Electoral Relevance of Traditional Cleavage Groups.” European Political Science Review 3 (2): 279-300.

Bischof, Daniel. 2017. "New Graphic Schemes for Stata: Plotplain and Plottig.” Stata Journal 17 (3): 748-59.

Boix, Carles. 1998. Political Parties, Growth and Equality: Conservative and Social Democratic Economic Strategies in the World Economy. Cambridge: Cambridge University Press.

Bonoli, Giuliano. 2005. "The Politics of the New Social Policies: Providing Coverage against New Social Risks in Mature Welfare States.” Policy and Politics 33 (3): 431-49.

Bonoli, Giuliano. 2013. The Origins of Active Social Policy: Labour Market and Childcare Polices in a Comparative Perspective. Oxford: Oxford University Press.

Bornschier, Simon. 2010. "The New Cultural Divide and the TwoDimensional Political Space in Western Europe." West European Politics 33 (3): 419-44.

Brady, David, Evelyne Huber, and John D. Stephens. 2014. Comparative Welfare States Data Set. Chapel Hill: University of North Carolina.

Brady, David, and Hang Y. Lee. 2014. "The Rise and Fall of Government Spending in Affluent Democracies, 1971-2008." Journal of European Social Policy 24 (1): 56-79.

Burgoon, Brian, and Fabian Dekker. 2010. "Flexible Employment, Economic Insecurity and Social Policy Preferences in Europe." Journal of European Social Policy 20 (2): 126-41.

Busemeyer, Marius R. 2009. "Social Democrats and the New Partisan Politics of Public Investment in Education." Journal of European Public Policy 16 (1): 107-26.

Busemeyer, Marius R., Simon T. Franzmann, and Julian L. Garritzmann. 2013. "Who Owns Education? Cleavage Structures in the Partisan Competition over Educational Expansion." West European Politics 36 (3): 521-46.

Busemeyer, Marius R., and Julian L. Garritzmann. 2017. "Public Opinion on Policy and Budgetary Trade-Offs in European Welfare States: Evidence from a New Comparative Survey." Journal of European Public Policy 24 (6): 871-89.

Busemeyer, Marius R., and Erik Neimanns. 2017. "Conflictive Preferences towards Social Investments and Transfers in Mature Welfare States: The Cases of Unemployment Benefits and Childcare Provision." Journal of European Social Policy 27 (3): 229-46.

Döring, Holger, and Philip Manow. 2018. Parliaments and Governments Database (ParlGov): Information on Parties, Elections and Cabinets in Modern Democracies. Development version. http://www.parlgov.org/. 
Emmenegger, Patrick. 2009. "Barriers to Entry: Insider/Outsider Politics and the Political Determinants of Job Security Regulations." Journal of European Social Policy 19 (2): 131-46.

Evans, Geoffrey, and James Tilley. 2012. "How Parties Shape Class Politics: Explaining the Decline of the Class Basis of Party Support." British Journal of Political Science 42 (1): 137-61.

Flanagan, Scott C., and Aie-Rie Lee. 2003. "The New Politics, Culture Wars, and the Authoritarian-Libertarian Value Change in Advanced Industrial Democracies." Comparative Political Studies 36 (3): 23570.

Fossati, Flavia, and Silja Häusermann. 2014. "Social Policy Preferences and Party Choice in the 2011 Swiss Elections.” Swiss Political Science Review 20 (4): 590-611.

Garritzmann, Julian L., Marius R. Busemeyer, and Erik Neimanns. 2018. "Public Demand for Social Investment: New Supporting Coalitions for Welfare State Reform in Western Europe?" Journal of European Public Policy 25 (6): 844-61.

Gingrich, Jane. 2014. "Visibility, Values, and Voters: The Informational Role of the Welfare State.” Journal of Politics 76 (2): 565-80.

Gingrich, Jane. 2017. "A New Progressive Coalition? The European Left in a Time of Change.” Political Quarterly 88 (1): 39-51.

Gingrich, Jane, and Ben Ansell. 2015. "The Dynamics of Social Investment: Human Capital, Activation, and Care.” In Pablo Beramendi, Silja Häusermann, Herbert Kitschelt, and Hans-Peter Kriesi, eds., The Politics of Advanced Capitalism. New York: Cambridge University Press, 282-304.

Gingrich, Jane, and Silja Häusermann. 2015. “The Decline of the WorkingClass Vote, the Reconfiguration of the Welfare Support Coalition and Consequences for the Welfare State." Journal of European Social Policy 25 (1): 50-75.

Häusermann, Silja. 2010a. The Politics of Welfare State Reform in Continental Europe. New York: Cambridge University Press.

Häusermann, Silja. 2010b. "Solidarity with Whom? Why Organised Labour Is Losing Ground in Continental Pension Politics." European Journal of Political Research 49 (2): 223-56.

Häusermann, Silja, and Hans-Peter Kriesi. 2015. "What Do Voters Want? Dimensions and Configurations in Individual-Level Preferences and Party Choice." In Pablo Beramendi, Silja Häusermann, Herbert Kitschelt, and Hans-Peter Kriesi, eds., The Politics of Advanced Capitalism. New York: Cambridge University Press, 202-30.

Häusermann, Silja, Thomas Kurer, and Hanna Schwander. 2015. "HighSkilled Outsiders? Labor Market Vulnerability, Education and Welfare State Preferences." Socio-Economic Review 13 (2): 235-58.

Häusermann, Silja, Gerard Picot, and Dominik Geering. 2013. "Rethinking Party Politics and the Welfare State: Recent Advances in the Literature." British Journal of Political Science 43 (1): 223-41.

Hemerijck, Anton. 2013. Changing Welfare States. Oxford: Oxford University Press.

Inglehart, Ronald. 1977. Silent Revolution: Changing Values and Political Styles among Western Publics. Princeton, NJ: Princeton University Press.

Iversen, Torben, and David Soskice. 2001. "An Asset Theory of Social Policy Preferences.” American Political Science Review 95 (4): 875-93.

Iversen, Torben, and David Soskice. 2015. "Information, Inequality, and Mass Polarization." Comparative Political Studies 48 (13): 1781-813.

Karreth, Johannes, Jonathan T. Polk, and Christopher S. Allen. 2013. "Catchall or Catch and Release? The Electoral Consequences of Social Democratic Parties' March to the Middle in Western Europe.” Comparative Political Studies 46 (7): 791-822.

Keman, Hans. 2011. "Third Ways and Social Democracy: The Right Way to Go?" British Journal of Political Science 41 (3): 671-80.
Kim, Sung E., and Yotam Margalit. 2017. "Informed Preferences? The Impact of Unions on Workers' Policy Views." American Journal of Political Science 61 (3): 728-43.

Kitschelt, Herbert. 1994. The Transformation of European Social Democracy. Cambridge Studies in Comparative Politics. Cambridge: Cambridge University Press.

Kitschelt, Herbert. 2012. "Social Class and Radical Right: Conceptualizing Political Preference Formation and Partisan Choice.” In Jens Rydgren, ed., Class Politics and the Radical Right. London: Routledge, 224-51.

Kitschelt, Herbert, and Philipp Rehm. 2014. "Occupations as a Site of Political Preference Formation.” Comparative Political Studies 47 (12): 1670-706.

Kraft, Jonas. 2017. "Political Parties and Public Investments: A Comparative Analysis of 22 Western Democracies." West European Politics 41 (1): 128-46.

Kriesi, Hans-Peter, Edgar Grande, Romain Lachat, Martin Dolezal, Simon Bornschier, and Timotheos Frey. 2008. West European Politics in the Age of Globalization. Cambridge: Cambridge University Press.

Lindvall, Johannes, and David Rueda. 2014. "The Insider-Outsider Dilemma." British Journal of Political Science 44 (2): 460-75.

Lipset, Seymour M. 1960. Political Man: The Social Bases of Politics. Garden City, NY: Doubleday.

Lohmann, Susanne. 1998. "An Information Rationale for the Power of Special Interests.” American Political Science Review 92 (4): 809-27.

Lowe, Will, Kenneth Benoit, Slava Mikhaylov, and Michael Laver. 2011. "Scaling Policy Preferences from Coded Political Texts." Legislative Studies Quarterly 36 (1): 123-55.

Marx, Paul. 2014. "Labour Market Risks and Political Preferences: The Case of Temporary Employment." European Journal of Political Research 53 (1): 136-59.

Morel, Nathalie, Bruno Palier, and Joakim Palme, eds. 2012. Towards a Social Investment Welfare State? Ideas, Policies and Challenges. Bristol: Policy.

Mosimann, Nadja, and Jonas Pontusson. 2017. "Solidaristic Unionism and Support for Redistribution in Contemporary Europe." World Politics 69 (3): 448-92.

Nickell, Stephen. 1981. "Biases in Dynamic Models with Fixed Effects." Econometrica 49 (6): 1417-26.

Oesch, Daniel. 2006a. "Coming to Grips with a Changing Class Structure: An Analysis of Employment Stratification in Britain, Germany, Sweden and Switzerland." International Sociology 21 (2): 263-88.

Oesch, Daniel. 2006b. Redrawing the Class Map: Stratification and Institutions in Britain, Germany, Sweden and Switzerland. Basingstoke: Palgrave Macmillan.

Pierson, Paul, ed. 2001. The New Politics of the Welfare State. Oxford: Oxford University Press.

Przeworski, Adam, and John D. Sprague. 1986. Paper Stones: A History of Electoral Socialism. Chicago: University of Chicago Press.

Rueda, David. 2005. "Insider-Outsider Politics in Industrialized Democracies: The Challenge to Social Democratic Parties." American Political Science Review 99 (1): 61-74.

Rydgren, Jens, ed. 2012. Class Politics and the Radical Right, London: Routledge.

Schmidt-Catran, Alexander W., and Malcolm Fairbrother. 2016. "The Random Effects in Multilevel Models: Getting Them Wrong and Getting Them Right." European Sociological Review 32 (1): 23-38.

Taylor-Gooby, Peter, ed. 2004. New Risks, New Welfare: The Transformation of the European Welfare State. Oxford: Oxford University Press.

van der Brug, Wouter, Gianni D'Amato, Didier Ruedin, and Joost Berkhout. 2015. The Politicisation of Migration. London: Routledge.

van Elsas, Erika J., Rozemarijn Lubbe, Tom W. G. van der Meer, and Wouter van der Brug. 2014. "Vote Recall: A Panel Study on the Mechanisms That 
Explain Vote Recall Inconsistency." International Journal of Public Opinion Research 26 (1): 18-40.

Visser, Jelle. 2013. ICTWSS: Database on Institutional Characteristics of Trade Unions, Wage Setting, State Intervention and Social Pacts in 34 Countries between 1960 and 2007, Amsterdam Institute for Advanced Labour Studies.

Volkens, Andrea, Pola Lehmann, Theres Matthieß, Nicolas Merz, Sven Regel, and Bernhard Weßels. 2017. The Manifesto Data Collection, version 2017b. Manifesto Project (MRG/CMP/MARPOR), Wissenschaftszentrum Berlin für Sozialforschung.

Wagner, Markus, and Thomas M. Meyer. 2017. "The Radical Right as Niche Parties? The Ideological Landscape of Party Systems in Western Europe, 1980-2014." Political Studies 65 (1S): 84-107.

Watson, Sara E. 2015. The Left Divided: The Development and Transformation of Advanced Welfare States. Oxford: Oxford University Press. 